\title{
Implementation of Educational Autonomy Through Community Empowerment in an Integrated Islamic School in Jambi City
}

\author{
Musli* \\ Islamic Education Management Department \\ Postgraduate Islamic State University of Sulthan Thaha \\ Saifuddin \\ Jambi, Indonesia \\ *mudamusli@gmail.com
}

\author{
Wahab, Irfan, Yusraini \\ Arabic Education Departments, Tarbiyah and Teacher \\ Training Faculty \\ Islamic State University of Sulthan Thaha Saifuddin \\ Jambi, Indonesia \\ wahab.tarbiyahiainjambi@gmail.com, \\ irfan76zahra@gmail.com, yusrainiyusraini@uinjambi.ac.id
}

\begin{abstract}
Educational autonomy allows the authority to gain wider space to manage natural and human resources in accordance with existing regional potentials. This article aimed to encourage participation from any parties related to broader educational autonomy, accommodate the realization of democratic principles, to reduce the costs due to long bureaucratic flows, opportunities to optimally utilize regional potential, accommodate political interests, and encourage more competitive product quality. This study used a qualitative research and the data were collected via observation, interviews, and documentation; for data analysis used descriptive technique. Based on the studies that had been done, it was found that the implementation of community empowerment in the era of educational autonomy, including: Program Planning and Evaluation, Curriculum Management, Management of Teaching and Learning Process, Manpower Management, Equipment and Supplies Management, Financial Management, Student Services, School and Community Relations, Climate Management
\end{abstract}

Keywords-educational autonomy, community empowerment, integrated Islamic School

\section{INTRODUCTION}

The centralistic implementation of education could kill the ability to create and innovate, which of course at this time must be by the development of an open democratic society. Therefore, the decentralization of education means that the process of education was closer to the people as the owner of education itself. People must innovate, participate, be creative, and be empowered in the formation of the education system. The participation of the people in the delivery of education in a democratic society also means that the people foster the birth of a nation's education decentralization.

In a democratic society, every member was required to participate optimally in the development of his personal life and society. In this shared life, high competitiveness in cooperation is required. Likewise, the problem of education, if the community is not empowered in the progress and development of education, of course, education will be difficult to develop and may slowly die.

Competitiveness in society is not the ability to kill and get rid of one another but in the framework of cooperation which is increasing in quality. The world of global education requires competitiveness from every individual, every society, and even every nation. The existence of a society and a nation can only be guaranteed if it continuously improves itself and empowers its abilities.

In educational autonomy, community empowerment by using its existing potentials will certainly be able to improve the quality of education that takes place in Indonesian society, because there are indeed many educational institutions in Indonesia that have succeeded brilliantly and created quality outcome through community empowerment by exploring all potential existing schools, rather than schools that are purely state-funded without any community empowerment in the management and journey of the educational process, which seem to be static and stagnant without changing.

According to Hasbullah [1], the form of autonomy in education is different from autonomy in other fields. Autonomy in the education sector does not stop at the district/city level but reaches the school level as the spearhead of education delivery. With the transfer of authority at the school level, schools are expected to be able to determine the direction of program development by the existing conditions and potential of the area.

According to Umiarso and Gojali [2], the concept of decentralized education is known as school-based management, which is a paradigm shift in education management, which was originally centered on the central government, shifting to education management in a management pattern where the school manages it. 
According to Umiarso and Gojali [2], the Ministry of National Education described that the aim of implementing School-based Management is to improve the quality of education through independence and school initiative in managing and empowering the existing resources available; increase the awareness of school members and the community in the implementation of education through joint decision making; increasing the school's responsibility to parents, the community and the government regarding the quality of the school; and increasing healthy competition between schools regarding the quality of education to be achieved [2]

According to Dressel [3], autonomy refers to "independence" (independence) or self-government (Autonomy refers to the independence of to government). Meanwhile, Berdhal, as quoted by Dressel, distinguishes aspects of autonomy into two (2) things, namely: 1) substantive, and 2) procedural. Substantive autonomy relates to rights that affect substantial matters as differentiated between matter and form. The substance is something that materially influences people's desires, which is guaranteed and protected by law. Substantive rights are anything fundamental, recognized, or pre-existing, such as life, freedom, wealth, and reputation. Everything is a personal right and guaranteed in the legal system of society. The extent of substantive autonomy for individuals, organizations, or groups is responsibility and accountability. Those who receive autonomy must accept certain duties and obligations.

Decentralization policy through educational autonomy will significantly influence education development. There are at least 4 positive impacts to support the education decentralization policy, namely: 1) Quality Improvement, that is, with the authority that schools have, schools can more freely manage and empower their potential resources; 2) Financial Efficiency, this can be achieved by utilizing local tax sources and reducing operational costs; 3) Administrative Efficiency, by cutting the long bureaucratic chain by eliminating multilevel procedures; 4) Expansion and equity, opening up opportunities for education in remote areas so that there are expansion and distribution of education [4].

The decentralization of education requires strengthening the basic foundation of education that is democratic, transparent, and efficient and involves the participation of local communities. Muctar Buchori stated that education is a determining factor for the success of human development because of education functions as a developer of knowledge, skills, values, and culture [5]. Through mental aspects of education, rationality, dignity, ethics, and aesthetics can be instilled. However, this decentralized education system is not everything if it is not followed by improvement efforts in various fields [6], because education in Indonesia faces some challenges that arise as a result of the globalization process, and the existence of a multi-dimensional crisis which results in changes in planning, policies, and management, and others.

Decentralization of education can occur in three levels, namely De-concentration, Delegation, and Devolution. De- concentration is the process of delegating a portion of authority to a lower government or institution with supervision from the center. Meanwhile, Delegation implies the complete handover of power so that it no longer requires supervision from the central government. At the level of devolution in the education sector, it occurs when it fulfills 4 characteristics, namely: 1) separate laws and regulations governing education at the regional and central levels; 2) freedom of regional institutions in managing education; 3) independent of hierarchical supervision from the center and 4) the authority of regional institutions is regulated by legislation [9].

Decentralization of Community Based Education implies a change in authority in the government, including). Changes related to functions that are not regulated by the central government will automatically become the responsibility of local governments, including in education management, and b) Changes about the decentralization of education management, in this case, the transfer of authority in the management of education and the central government in autonomous regions, placing districts/cities as centers of decentralization [3].

Decentralization in educational autonomy has also proven successes, among others: 1) Able to fulfill political objectives, namely implementing democratization in the management of education, 2) Able to build community participation to produce relevant education, because education is really from by and for the community, 3) Able to organize education by facilitating a conducive teaching and learning process, which in turn will improve the quality of student learning [3].

Community empowerment is a process from, by, and for the community, in which the community is assisted/facilitated in making decisions and taking their initiatives so that brands are more independent in the development and improvement of their standard of living, while other parties only function as facilitators.

In more detail, what is meant by empowered people is people who know, understand, understand motivated, have the opportunity, take advantage of opportunities, have energy, can cooperate, know various alternatives, can make decisions, dare to take risks, can seek and capture information and can act accordingly. with the situation. The empowerment process that gives birth to a community that has the characteristics as expected must be carried out sustainably by optimizing community participation in a responsible manner.

According to Islam, empowerment in educational autonomy is the joint responsibility of several parties who are implementing education to make education empowered and have the ability to improve its quality because in Islam, change to be empowered must be carried out with concerted effort, no one can be empowered without effort, serious and earnest. Allah said (in fact Allah will not change the fate of a people, so they change their destiny). So empowerment is an obligation that is imposed on every individual and stakeholder of educational institutions, as expressed by Naceur Jabnouk [7], that every human being (be it individuals or groups and institutions) has the responsibility to live his life now until the 
hereafter, there are many arguments. Which states that "everyone is responsible for what he has done" (QS. 74; 38) [8].

The concept of empowerment has been used in various aspects of life, including in education. School-based management of SBM is a concept of school empowerment that is in line with the decentralized paradigm, which is to empower the role of schools and communities in supporting the management and implementation of education in schools through the provision of autonomy and flexibility to schools to make decisions and encourage direct participation of school members and the community. to improve the quality of schools [9].

School-Based Management can be interpreted as a management model that provides greater autonomy (authority and responsibility) to schools, provides flexibility to schools, and encourages direct participation of school members and the community to improve the quality of schools based on national education policies and applicable laws [10].

The birth of the concept of empowerment is the antithesis of a development model that does not favor the majority of the people. This concept is built from the following logical framework: a) The process of concentration of power is built from the concentration of power in the factors of production ; b) The concentration of power in the factors of production will give birth to a working society and a community of marginal entrepreneurs; c) Power will build the building of knowledge systems, political systems, legal systems, and ideological systems that are manipulative to strengthen legitimacy; d) The systematic implementation of knowledge systems, political systems, legal systems, and ideologies will create two groups of people, namely the empowered and the disabled. Finally, what happens is a dichotomy, namely ruling society and ruling humans. To free the situation of control and control, liberation must be carried out through a process of empowerment for the weak [11].

One thing that needs to be realized is the plurality of society, culture, and geography of Indonesia, with uniformity of public education means education against existing facts, education that is not grounded. So naturally, the education system that needs to be built in the era of autonomy is a plural community-based education. Community-based education is essentially education that originates, takes place, and is oriented towards the needs of the community. The ultimate goal is community empowerment with educational programs that touch directly the real life of local communities.

In community empowerment for educational autonomy, several elements need to be implemented, as expressed by Fasli [12], namely, the application of integrated quality management (TQM) in education, Application of Educational management professionalism, increasing welfare and implementing teacher career development systems. Enforcing the legality of education delivery.

\section{RESEARCH METHOD}

The kind of this research was qualitative, with the approach in the form of implementation of educational autonomy through community empowerment in integrated Islamic elementary schools in Jambi city. According to Yin [13], this research approach was more explanatory and leads to the use of a case study strategy.

The data were gathered from observation, interviews, and documented study that are recorded through notes or recording audiotapes, photos, and others [14]. The interview was conducted by interviewing several people including educational institutions, related agencies, parents of students and the community related to community empowerment in educational autonomy. While the observations made were related to community empowerment in educational autonomy at SDIT. For data analysis in this study, researchers used an interactive analysis containing four interrelated components, namely: data collection, data simplification, data exposure, and drawing and submission of conclusions.

\section{RESULTS AND DISCUSSSION}

The implementation of educational autonomy through community empowerment at SDIT in Jambi city, based on the results of interviews and observations, it is known that all of stakeholders in an educational institution can be properly utilized and managed according to the level of needs and the predetermined vision and mission. Integrated Islamic Primary Schools have sprung up in the city of Jambi and almost every district has established these schools. SDIT in the process of educational activities is independent and empowers the community to progress and improve the quality of their education

Based on the results of observations, interviews, and documentation of researchers and some data obtained from several integrated Islamic elementary schools in the city of Jambi, regarding the implementation of community empowerment in the era of educational autonomy, including:

\section{A. Program Planning and Evaluation}

Based on the author's observations, several things made program planning and evaluation not going well. First, some schools, especially schools with private status, still had many shortcomings considering that the full implementation of education was managed by the foundation. Of course, there were still shortcomings that need to be addressed and it took time. Second, the existing resources in schools (adequate teaching staff and regional potential) have not been supported by supporting facilities. To produce quality output, of course, the educational institution in charge of printing quality human resources must be supported by facilities in the region so that the output produced does not go to waste. Third, the community's participation has not been maximal in the process of providing education in terms of planning, implementation, and evaluation of the education process. 


\section{B. Curriculum Management}

Currently, the management of the curriculum for several schools, especially schools with private status, had gone well with the presence of suitable teaching staff. Several competency standards have been applied in several schools, especially schools with private status. Such as SDIT Ash Shiddiqi, NurulIlmi, and al Azhar, wherein their curriculum they followed the curriculum applicable in the national education ministry and were added to the curriculum from the integrated Islamic school network.

\section{Management of Teaching and Learning Process}

Based on observations made by researchers in the teaching and learning process in several schools, especially integrated Islamic elementary schools, it has started to run well. Runs according to the syllabus and basic school competencies. However, to improve the quality of good education, of course, the teaching and learning process must be supported by other means. And to fulfill this, all the support and participation of the community who use education services need to be explored and empowered to achieve common desires and goals, namely quality education.

\section{Manpower Management}

Based on the results of interviews and observations of researchers at SDIT An-Nahl, Al-Azhar, and Nurul Ilmi, it is known that workforce management in integrated Islamic elementary schools has the authority to manage energy starting from planning needs analysis, recruitment, development, rewards, and sanctions, work relations to evaluating workforce performance. For school progress, it is the school that understands its needs, as well as the needs of its educators. For financing, the school collaborates with school committees and the community so that the education delivery process runs well. In managing personnel, schools involve the community, especially those who are members of the school committee, to discuss the need for honorary staff.

\section{E. Equipment and Supplies Management}

The quality of education, apart from being seen from the teaching and learning process, must also be supported by supporting facilities such as good, complete, and adequate practice tools. The implementation of school-based management involves the participation of stakeholders for the progress of education delivery. Based on observations and interviews of researchers at SDIT Ash Shiddiqi regarding the management of equipment and equipment, it has involved stakeholders such as the users of the education alumni or various companies that are competing to hold and MoU with the school.

\section{F. Financial Management}

With educational autonomy, especially for students in integrated Islamic elementary schools based on observations and observations of researchers, it was found that financial management was carried out to be more observant in seeing various opportunities for financial income so that the education budget did not only come from APBD assistance funds. The school also involves the community and it should not only be financing for honorary staff. Schools can invite people to work together to open businesses to generate profits such as managing business results, leasing, submitting proposals, and others.

\section{G. Student Services}

Student management is of course carried out continuously so that schools can create a conducive atmosphere. According to Umiarso and Gojali [2] Student management is one of the operational areas of school-based management. Student management is the entire process of activities that are planned and attempted on purpose as well as continuous guidance for all students so that they can follow the teaching and learning process effectively and efficiently. Therefore, student management is not only in the form of recording student data from a school, but a broader aspect that can operationally assist the growth and development of students through the education process in schools.

\section{H. School and Community Relations}

Integrated Islamic elementary schools are a school model that opens wide spaces for community participation. The relationship that the school makes is not only to the community (parents of students), but the school also makes relationships with other schools in the form of socialization. Also, the school's relationship with the community in addition to funding educators, a form of community participation in schools by providing opportunities for students to become entrepreneurs, such as holding a student bazaar for students, parents, and the community.

\section{Climate Management}

A conducive and academic school climate is a prerequisite for the implementation of an effective teaching and learning process. A safe and orderly school environment, high optimism and expectations from the school community, school health, and student-centered activities are examples of a school climate that can foster student enthusiasm for learning.

In an integrated Islamic elementary school, the school climate that is managed by the school is a family attitude between teachers and students. Besides, the results obtained are student achievement which can be seen in sending students to participate in various competitions and student competencies to get good achievements. This will be able to manage the school climate and school image.

\section{J. Community Participation in Education}

In integrated Islamic primary schools, efforts to foster relationships and cooperation between schools and the community already have an agency that can become a place for community participation for the advancement of education in the regions, namely the school committee. Community 
participation with school committees can be seen in school financing. The existence of deliberation in determining the number of costs that must be incurred by the parents of students identifies a good relationship between the school and the community. The school committee's job is also to supervise students who roam around during school hours. The community or school committee has become an obligation to convey student behavior while the student is wearing school clothes. SDIT always involves the community for school activities, regarding human resources, curriculum, facilities and infrastructure, information systems, and everything that is considered related (figure 1).

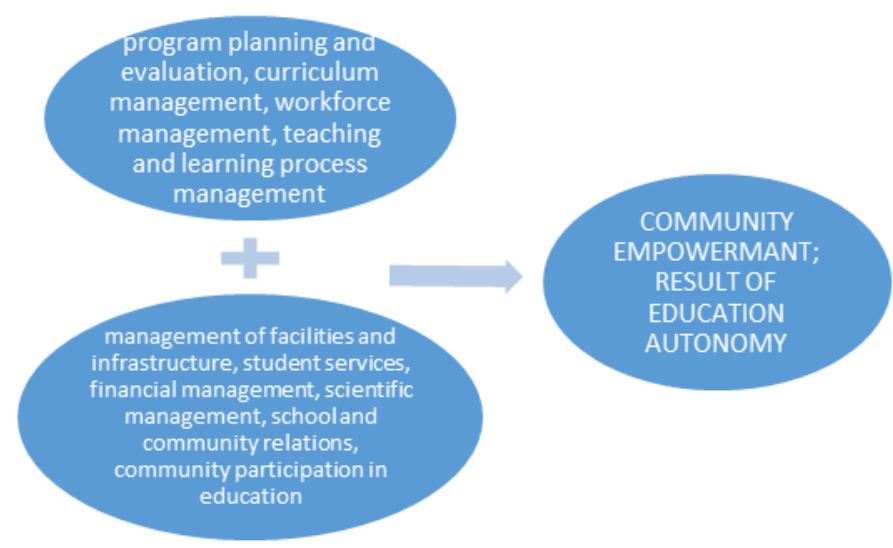

Fig. 1. Resulst of education autonomy.

\section{CONCLUSION}

The implementation of community empowerment in the era of educational autonomy, including: Program Planning and Evaluation, Curriculum Management, Management of Teaching and Learning Process, Manpower Management, Equipment and Supplies Management, Financial Management, Student Services, School and Community Relations, Climate Management

Educational autonomy is the authority in providing wider space for schools to manage natural resources and human resources by existing regional potentials. With the following reasons: Encouraging wider participation from below, Accommodating the realization of democratic principles, reducing costs due to long bureaucratic flows to increase efficiency, providing opportunities to optimally utilize regional potential,

Community empowerment is a process from, by, and for the community, where people are facilitated in making decisions and taking their initiatives so that brands are more independent in the development and improvement of their lives, while other parties only function as facilitators.

The implementation of educational autonomy through community empowerment can be carried out including, program planning and evaluation, curriculum management, workforce management, teaching and learning process management, management of facilities and infrastructure, student services, financial management, scientific management, school and community relations, community participation in education.

\section{ACKNOWLEDGMENT}

The authors acknowledge all of the participants in this study.

\section{REFERENCES}

[1] R.A. Gerungan, "Otonomi Pendidikan (Kebijakan Otonomi Daerah Dan Implikasinya Terhadap Penyelenggaraan Pendidikan)," Jakarta Div. Buku Perguru. Tinggi PT. RajaGrafindoPersada, 2006.

[2] I.G. Umiarso, "Manajemen Mutu Sekolah Di Era Otonomi Pendidikan," Yogyakarta CV. Andi Offset, 2010.

[3] Dressel, "Otonomi Pendidikan: Permasalahan Dan SolusI," 2010 http://salmaneducainfo.blogspot.com/2010/11/otonomi-pendidikanpermasalahan-dan.html.

[4] E. Mulyasa, "Manajemen Berbasis Sekolah: Konsep, Strategi Dan Implementasi," 2004.

[5] M. Buchori, Partisipasi Masyarakat Demokratis Di Indonesia. Jakarta: BumiAksara, 2001.

[6] M. Pidarta, "Perencanaan Pendidikan Partisipatori Dengan Pendekatan Sistem,” Jakarta: Rineka Cipta, 2005.

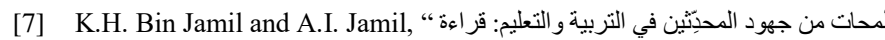
في ضوء مباحث الإدارة التربوية: The Muhaddithin’s Practices in Teaching and Education: A Reading from the Perspective of Educational Administration,” J. Islam. Educ. Res., vol. 4, pp. 31-41, 2019.

[8] Alqur'an dan Terjemahannya. .

[9] D. Rosyada, "Paradigma Pendidikan Demokratis: Sebuah Model Pelibatan Masyarakat Dalam Penyelenggaraan Pendidikan Jakarta: PT." Kencana, 2004.

[10] V.B.M. Sekolah, "Dari Unit Birokrasi Ke Lembaga Akademik,” Jakarta Bumi Aksara, 2006

[11] T. Mardikanto and P. Soebianto, "Community Empowerment in Perspective of Public Policy (In Indonesia: Pemberdayaan Masyarakat Dalam Perspektif Kebijakan Publik)," Bandung CV Alf., 2012.

[12] F. Jalal and D. Supriadi, Reformasi pendidikan dalam konteks otonomi daerah. Diterbitkan atas kerjasama Depdiknas, Bappenas, Adicita Karya Nusa, 2001

[13] R.K. Yin, "Yin, Robert K., Case Study Research: Design and Methods, Newbury Park, CA: Sage, 1994.," 1994.

[14] S. Nasution, Metode penelitian naturalistik kualitatif. Tarsito, 1988. 